\title{
Oropharyngeal (p16-Negative) Cancer Pathologic TNM Finding v8
}

National Cancer Institute

\section{Source}

National Cancer Institute. Oropharyngeal (p16-Negative) Cancer Pathologic TNM Finding v8. NCI Thesaurus. Code C132912.

A pathologic finding about one or more characteristics of p16-negative oropharyngeal cancer, following the rules of the TNM AJCC v8 classification system. 